\section{POS0930 SECUKINUMAB IN PATIENTS WITH PSORIATIC ARTHRITIS AND AXIAL MANIFESTATIONS: PREDICTORS OF RESPONSE FROM THE DOUBLE- BLIND, RANDOMISED, PHASE 3B MAXIMISE TRIAL}

X. Baraliakos ${ }^{1}$, E. Pournara ${ }^{2}$, L. Gossec ${ }^{3}$, H. Marzo-Ortega ${ }^{4}$, P. J. Mease ${ }^{5}$, R. White ${ }^{6}$, E. O'brien ${ }^{6}$, B. Schulz ${ }^{2}$, L. C. Coates ${ }^{7} .{ }^{1}$ Ruhr-University Bochum, Rheumazentrum Ruhrgebiet, Herne, Germany; ${ }^{2}$ Novartis Pharma AG., Immunology, Hepatology and Dermatology, Basel, Switzerland; ${ }^{3}$ Sorbonne Universite, Hopital Pitie-Salpetriere, Paris, France: ${ }^{4}$ University of Leeds, NIHR Leeds Biomedical Research Centre, Leeds, United Kingdom; ${ }^{5}$ Providence St Joseph Health and University of Washington, Swedish Medical Centre, Seattle, United States of America; ${ }^{6}$ Novartis Ireland Limited, NBS CONEXTS, Dublin, Ireland; ${ }^{7}$ University of Oxford, Nuffield Department of Orthopaedics, Rheumatology and Musculoskeletal Sciences, Oxford, United Kingdom

Background: Psoriatic arthritis (PsA) is a heterogeneous disease with variability of response to different therapeutic modalities. ${ }^{1}$ Identifying potential demographic and disease characteristics as predictors of treatment response may define personalised treatment optimisation strategies. ${ }^{2-3}$

Objectives: This post-hoc exploratory analysis of the MAXIMISE trial ${ }^{4}$ investigated the differential treatment effect of demographics and baseline characteristics as predictive factors in biologic naïve patients with active PsA and symptoms of active spinal disease.

Methods: The full analysis set (FAS) comprised of all patients from the randomised set assigned to study treatment, fulfilling the predefined clinical criteria for active axial disease and for whom Assessment of SpondyloArthritis International Society (ASAS) 20 data were available at Week 12. The research hypothesis was that the odds ratio associated with the effect of treatment on ASAS20 responder status at Week 12 would be different depending on 12 pre-specified predictor variables. A logistic regression model was initially fitted to the FAS that included 12 pre-specified covariates. A second logistic regression model was then fitted to the FAS that allowed for all 12 pre-specified variables to interact with treatment. ${ }^{5}$ The log-likelihood of the two fitted models were compared using a likelihood ratio test at a pre-specified significance level of $20 \%$ (i.e. $P$-value $\leq 0.20$ ) to test whether any of the predefined variables interacted with treatment. If the above test was statistically significant at the $20 \%$ level of statistical significance the variables of the second model were formally examined to determine whether the overall effect of treatment is not applicable. Three forest plots were produced, one for each treatment group. Hypothesis tests were employed to determine the strength of evidence for each individual variable. Results: The likelihood ratio test provided evidence against the assumption that the overall effect of treatment is applicable to all patients $(P$-value $=0.08)$. Notably, the odds of being an ASAS20 responder if nail dystrophy is present at baseline were 3 times greater in the secukinumab $150 \mathrm{mg}$ group and 5 times greater in the $300 \mathrm{mg}$ group compared with placebo (interaction $P$-value $=0.029$ ). Although males fare worse than females in the placebo group, in the secukinumab $150 \mathrm{mg}$ and $300 \mathrm{mg}$ treatment groups the odds of being a responder were similar to females (interaction $P$-value $=0.039$ ). Current smokers were less likely to be ASAS20 responders compared to never smokers regardless of treatment group (interaction $P$-value $=0.589$ ) (Figure 1). Age, CRP level, Berlin MRI spine/SIJ score, time since first axial signs, number of swollen joints, new bone formation and BMI did not show a differential treatment effect on ASAS20 responses.

Conclusion: Of the 12 baseline variables of a unique population of $473 \mathrm{PsA}$ patients with active axial disease diagnosed by clinical criteria, our analyses showed evidence of a differential treatment effect most notably for nail dystrophy suggesting that the presence of nail dystrophy may predict a better response to secukinumab in PsA patients with axial manifestations.

REFERENCES:

[1] Coates LC, Helliwell PS. Clin Med (Lond). 2017;17(1):65-70.

[2] Watson DS, et al. BMJ. 2019;364:I886.

[3] Hügle M, et al. Rheumatol Adv Pract. 2020;4(1):rkaa005.

[4] Baraliakos X, et al. Ann Rheum Dis. Published Online First: 17 Dec 2020. doi:10.1136/annrheumdis-2020-218808.

[5] Peto R, et al. Br J Cancer. 1977;35(1):1-39.

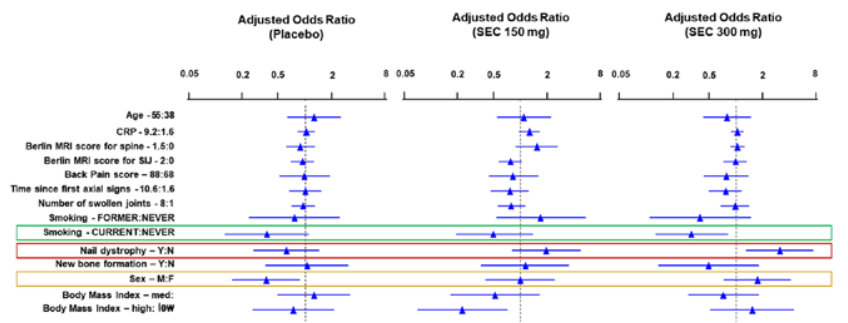

Figure 1. Forest plots of the adjusted odds ratio by treatment using interaction modelDisclosure of Interests:
Xenofon Baraliakos Speakers bureau: AbbVie, BMS, Celgene, Chugai, MSD, Novartis, Pfizer, and UCB., Consultant of: AbbVie, BMS, Celgene, Chugai, Galapagos, Gilead, MSD, Novartis, Pfizer, and UCB., Grant/research support from AbbVie, and Novartis., Effie Pournara Shareholder of: Novartis, Employee of: Novartis, Laure Gossec Consultant of: AbbVie, Amgen, BMS, Biogen, Celgene, Gilead, Janssen, Lilly, Novartis, Pfizer, Samsung Bioepis, Sanofi-Aventis, and UCB., Grant/research support from: Amgen, Lilly, Janssen, Pfizer, Sandoz, Sanofi, and Galapagos., Helena Marzo-Ortega Consultant of: Janssen, Novartis, AbbVie, Celgene, Lilly, Pfizer, Takeda and UCB., Grant/research support from: Janssen, Novartis, AbbVie, Celgene, Lilly, Pfizer, Takeda and UCB., Philip J Mease Speakers bureau: AbbVie, Amgen, Genentech, Janssen, Lilly, Merck, Novartis, Pfizer and UCB., Consultant of: AbbVie, Amgen, BMS, Boehringer Ingelheim, Galapagos, Celgene, Genentech, Gilead, Janssen, Lilly, Novartis, Pfizer, SUN Pharma, and UCB., Grant/research support from: AbbVie, Amgen, BMS, Celgene, Galapagos, Genentech, Gilead, Janssen, Lilly, Merck, Novartis, Pfizer, SUN, and UCB., Roisin White Shareholder of: Novartis, Employee of: Novartis, Eamonn O'Brien Shareholder of: Novartis, Employee of: Novartis, Barbara Schulz Employee of: Novartis, Laura C Coates Speakers bureau: AbbVie, Amgen, Biogen, Celgene, Gilead, Eli Lilly, Janssen, Medac, Novartis, Pfizer, and UCB., Consultant of: AbbVie, Amgen, Boehringer Ingelheim Bristol-Myers Squibb, Celgene, Eli Lilly, Gilead, Janssen, Novartis, Pfizer, and UCB., Grant/research support from: AbbVie, Amgen, Celgene, Eli Lilly, Pfizer, and Novartis.

DOI: 10.1136/annrheumdis-2021-eular.2456

\begin{tabular}{|l|l}
\hline POS0931 & RETENTION RATE AND TREATMENT \\
RESPONSE OF BIOLOGICAL AGENTS IN \\
ADVANCED SPINAL ANKYLOSIS AND BAMBOO \\
SPINE: THE REAL LIFE DATA FROM THE HUR- \\
BIO REGISTRY
\end{tabular}

B. Farisoğulları ${ }^{1}$, G. K. Yardımcı ${ }^{1}$, E. C. Bolek ${ }^{1}$, E. Bilgin ${ }^{1}$, E. Duran ${ }^{1}$, G. Ayan ${ }^{1}$ Z. Özsoy ${ }^{1}$, G. Sandal Uzun ${ }^{1}$, L. Kılıç ${ }^{1}$, A. Akdoğan ${ }^{1}$, S. A. Bilgen ${ }^{1}$, O. Karadag ${ }^{1}$, S. Kiraz ${ }^{1}$, A. İ. Ertenli ${ }^{1}$, U. Kalyoncu ${ }^{1} .{ }^{1}$ Hacettepe University, Faculty of Medicine, Department of Internal Medicine, Division of Rheumatology, Ankara, Turkey

Background: Axial spondyloarthritis (axSpA) may lead to linear radiographic progression and progress to advanced spinal disease and finally to the bamboo spine (1)

Objectives: To assess the demographic, clinical, disease activity and retention rates of patients using biological disease-modifying antirheumatic drugs (bDMARD) with advanced spinal disease and bamboo spine in the Hacettepe University Rheumatology Biologic Registry (HUR-BIO) cohort.

Methods: In the HUR-BIO spondyloarthritis (SpA) registry were available 2952 patients. Of these, 774 patients with lumbar and cervical radiographs were included in the study. Advanced spinal ankyloses (99 patients) was defined as the presence of at least two intervertebral adjacent bridges at the lumbar and/ or cervical spine level without bamboo spine. Bamboo spine (78 patients) was defined with a complete fusion of all lumbar and cervical spines. In addition, patients who diagnosed with axSpA for at least 10 years but no develop syndesmophytes on lumbar and cervical spine (92 patients) were used as a contro group.

Results: Both the bamboo spine and advanced spinal disease had higher age, higher BMI, more smoking (ever) and hip involvement compared to the without syndesmophytes group. Acute phase reactants, Bath Ankylosing Spondylitis Disease Activity Index (BASDAI), Bath Ankylosing Spondylitis Functional Index (BASFI), Ankylosing spondylitis disease activity ScoreCRP (ASDAS-CRP) parameters were similar at the beginning of bDMARD in all groups. BASFI was higher in the bamboo spine group than in the without syndesmophytes group at last visit (Table 1). There were no differences between all groups in terms of the retention rate of the first bDMARD (Log rank $\mathrm{p}=0.86$ ) (Figure 1)

Conclusion: Data on the use of bDMARDs in SpA patients with bamboo spine are limited. This study showed that bDMARDs are an effective treatment option in SpA patients with bamboo spine with high disease activity. Similar drug retention rates were found compared to SpA patients with no syndesmophytes. Although the disease activity decreased similar rates in the groups, functional limitation continued in approximately half of the patients in bamboo spine patients.

\section{REFERENCES:}

[1] Braun $J$ et al. Staging of patients with ankylosing spondylitis: a preliminary proposal. Annals of the rheumatic diseases, 2002, 61.suppl 3: iii19-iii23. 
Table 1. Demographic, clinical characteristics and response to treatment in SpA groups.

\begin{tabular}{|c|c|c|c|c|c|c|c|c|}
\hline & \multicolumn{2}{|c|}{$\begin{array}{c}\text { Without } \\
\text { syndesmophytes } \\
\mathrm{n}=92\end{array}$} & \multicolumn{2}{|c|}{$\begin{array}{c}\text { Advanced spinal } \\
\text { disease } \\
n=99\end{array}$} & \multicolumn{2}{|c|}{$\begin{array}{c}\text { Bamboo spine } \\
n=78\end{array}$} & \multicolumn{2}{|c|}{ p } \\
\hline Age, years $^{\circ}$ & \multirow{2}{*}{\multicolumn{2}{|c|}{$\begin{array}{l}42.2 \pm 8.8 \\
25.01(11)\end{array}$}} & \multirow{2}{*}{\multicolumn{2}{|c|}{$\begin{array}{l}51.3 \pm 10.2 \\
36.6(20)\end{array}$}} & \multirow{2}{*}{\multicolumn{2}{|c|}{$\begin{array}{c}55.5 \pm 9.3 \\
33.3(18)\end{array}$}} & \multicolumn{2}{|c|}{$<0.001^{*}$} \\
\hline $\begin{array}{l}\text { Age at disease } \\
\text { onset, years }\end{array}$ & & & & & & & $<0.0$ & $01^{*}$ \\
\hline Male, n (\%) & \multicolumn{2}{|c|}{$55(59.8)$} & \multicolumn{2}{|c|}{$78(78.8)$} & \multicolumn{2}{|c|}{$66(84.6)$} & \multicolumn{2}{|c|}{$<0.001^{*}$} \\
\hline $\begin{array}{l}\text { Disease dura- } \\
\text { tion, years }\end{array}$ & \multicolumn{2}{|c|}{$13.8(5)$} & \multicolumn{2}{|c|}{$12.3(15)$} & \multicolumn{2}{|c|}{$17.6(13)$} & \multicolumn{2}{|c|}{$<0.001^{*}$} \\
\hline $\begin{array}{l}\text { Delay in diagno- } \\
\text { sis, months }\end{array}$ & \multicolumn{2}{|c|}{$12.02(43)$} & \multicolumn{2}{|c|}{36.01 (89) } & \multicolumn{2}{|c|}{$36.01(100)$} & \multicolumn{2}{|c|}{$0.013^{\star}$} \\
\hline $\begin{array}{l}\text { HLA-B27 positiv- } \\
\text { ity/total, } n(\%)\end{array}$ & \multicolumn{2}{|c|}{$21 / 42(50)$} & \multicolumn{2}{|c|}{$31 / 45$ (69) } & \multicolumn{2}{|c|}{$16 / 28(57)$} & \multicolumn{2}{|c|}{0.19} \\
\hline BMI $^{2}$ & \multicolumn{2}{|c|}{$26.3(8)$} & \multicolumn{2}{|c|}{$29.7(7)$} & \multicolumn{2}{|c|}{$29.4(7)$} & \multicolumn{2}{|c|}{$<0.001^{*}$} \\
\hline $\begin{array}{l}\text { Smoking (ever), } \\
\text { n (\%) }\end{array}$ & \multicolumn{2}{|c|}{$56(61)$} & \multicolumn{2}{|c|}{$78(79)$} & \multicolumn{2}{|c|}{$58(74)$} & \multicolumn{2}{|c|}{$0.019^{\star}$} \\
\hline \multirow{2}{*}{$\begin{array}{l}\text { Hip involvement, } \\
\text { positivity/total } \\
(\%)\end{array}$} & \multicolumn{2}{|c|}{$11 / 84(13.1)$} & \multicolumn{2}{|c|}{ 34/86 (39.5) } & \multicolumn{2}{|c|}{ 37/75 (49.3) } & $<0.0$ & $01^{*}$ \\
\hline & Onset & Last & Onset & Last & Onset & Last & p (onset) & $p$ (last) \\
\hline ESR, mm/h & $21.5(34)$ & $12.5(18)$ & $25.5(29)$ & $14.5(17)$ & $23(31)$ & $14(14)$ & 0.6 & 0.59 \\
\hline CRP, mg/dL & $1.5(4)$ & $0.4(0.6)$ & $1.7(2)$ & $0.65(1)$ & $1.8(3)$ & $\begin{array}{c}0.64 \\
(0.8)\end{array}$ & 0.4 & $0.001^{*}$ \\
\hline ASDAS-CRP & $3.6(0.8)$ & $1.9(1)$ & $3.4(0.9)$ & $2(1.2)$ & $3.4(0.8)$ & $1.9(1.4)$ & 0.4 & 0.23 \\
\hline BASDAI score & $5.7(2.6)$ & $2.4(4.5)$ & $5.6(3.3)$ & $2.8(3.1)$ & $5.6(3.2)$ & $2.4(3.3)$ & 1 & 0.31 \\
\hline BASFI score & $5.4(4)$ & $2(4)$ & $4.5(4)$ & $3(4)$ & $6.5(3)$ & $3.9(4.5)$ & 0.1 & $0.002^{*}$ \\
\hline $\begin{array}{l}\text { BASFI score }>4 \text {, } \\
n(\%)\end{array}$ & 29 (59) & $23(25)$ & $29(56)$ & $32(32)$ & $27(75)$ & $36(46)$ & 0.1 & $0.014^{*}$ \\
\hline ASAS PR, n (\%) & & $26(28)$ & & $15(15)$ & & $17(22)$ & & 0.09 \\
\hline
\end{tabular}

${ }^{*} p<0.05$, ${ }^{\circ}$ mean \pm SD, median (IQR)SD: Standard deviation; IQR: Inter-quartile rangeBASDAI: Bath Ankylosing Spondylitis Disease Activity Index; BASFI: Bath Ankylosing Spondylitis Functional Index; BMI: Body mass index; ESR: Erythrocyte sedimentation rate; CRP: C-reactive protein; ASAS PR: Assessment in SpondyloArthritis International Society partial remission; ASDAS: Ankylosing spondylitis disease activity score

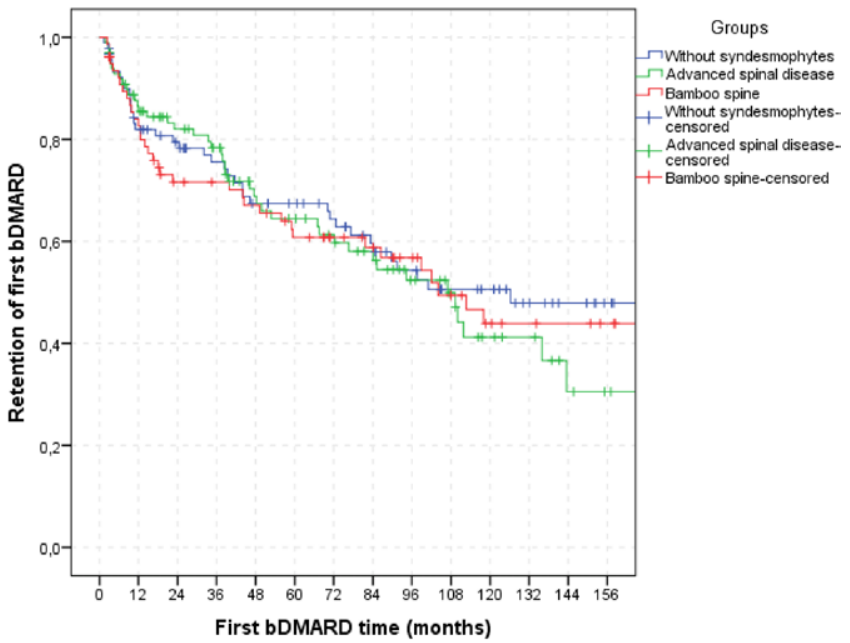

Figure 1. Retention rate of the first bDMARD

Disclosure of Interests: None declared

DOI: 10.1136/annrheumdis-2021-eular.2468

\section{\begin{tabular}{|l|l}
\hline POS0932 REGULATION OF INTESTINAL FLORA RESTORES \\
\hline
\end{tabular} IMMUNE BALANCE IN PATIENTS WITH UNDIFFERENTIATED SPONDYLOARTHRITIS}

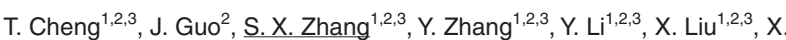
F. Yin ${ }^{1,2,3}$, X. Li ${ }^{1,2,3}{ }^{1}$ The Second Hospital of Shanxi Medical University, Department of Rheumatology, Taiyuan, China; ${ }^{2}$ Shanxi Li Xiaofeng Medical Groups, Department of Rheumatology, Taiyuan, China; ${ }^{3}$ Ministry of Education, Key Laboratory of Cellular Physiology at Shanxi Medical University, Taiyuan, China

Background: Undifferentiated spondyloarthritis (USpA) is the most common subtype of the spondyloarthritides with a prevalence between $0.7 \%$ and $2.0 \%{ }^{1}$. Inflammatory back pain, peripheral arthritis and less frequently enthesitis are the main clinical features of USpA ${ }^{2}$. Resently the role of dysregulated microbiome along with migration of $\mathrm{T}$ lymphocytes and other cells from gut to the joint ("gutjoint" axis) has been recognized ${ }^{34}$. However, the detailed lymphocyte statuses of USpA patients and the effect of regulating the intestinal flora on the lymphocyte subsets is unclear.

Objectives: To investigate the status of lymphocyte subsets in peripheral blood (PB) of USpA patients and the variation after regulation of intestinal flora.

Methods: A total of 39 newly diagnosed patients with USpA who fulfilled the European Spondyloarthropathy Study Group (ESSG) classification criteria and 60 age- and sex-matched healthy controls $(\mathrm{HC})$ were enrolled in this study. All patients were given intestinal flora regulation therapy for six months, including clostridium butyricum capsule or bacillus coagulans tablet. The peripheral lymphocyte subsets of these participants were assessed by flow cytometry. Methane hydrogen breath test as well as cytokines were measured in all patients before and after treatment. Mann-Whitney $\mathrm{U}$ test was applied for the lymphocyte status between USpA patients and $\mathrm{HC}$ and Wilcoxon test for the comparison before and after treatment. The results of methane hydrogen breath were counted by the Chi-Square test. All $P$-values reported herein are two-tailed and $P$-value $<0.05$ was taken as statistically significant.

Results: Compared with HC, patients with USpA had a lower numbers of T cells $(P=0.001)$, NK cells $(P=0.026), \mathrm{CD} 8+\mathrm{T}$ cells $(P=0.046)$ and Treg cells $(P<0.05)$ but higher ratios of Th17/Tregs $(P=0.001)$, indicating a disturbance of immune microenvironment (Figure 1). After given therapy, T cells $(P=0.003)$, B cells $(P=0.018)$, NK cells $(P=0.003), \mathrm{CD} 8^{+} \mathrm{T}$ cells $(P=0.001)$ and Treg cells $(P=0.009)$ were distinctly increased while the ratio of Th17/Treg decreased $(P=0.046)$, suggesting a rebalance of immune systems (Figure 2a-c). Moreover, there were increase in the level of IL-6 $(P<0.001)$, IL-17 $(P=0.029)$ and TNF- $\alpha(P=0.003)$ as well as decrease in IL-10 $(P=0.045)$ and IFN- $\gamma(P=0.001)$ (Figure $2 \mathrm{~d})$. Further, the positive rate of intestinal bacterial overgrowth decreased significantly after regulation $(P=0.029)$ (Figure $2 \mathrm{e}$ ).

Conclusion: Imbalance of immune environment is closely related to the incidence of undifferentiated spondyloarthrosis. The regulation of intestinal flora restores the balance and improve the growth of bacteria in the small intestine simultaneously. Therefore it is essential to focus on the alteration of intestinal flora to prevent the outbreak of inflammation and disease progression.

\section{ERENCES:}

[1] Cruzat V, Cuchacovich R, Espinoza LR. Undifferentiated spondyloarthritis: recent clinical and therapeutic advances. Curr Rheumatol Rep 2010;12(5):311-7. doi: 10.1007/s11926-010-0115-0 [published Online First: 2010/07/16].

[2] Deodhar A, Miossec P, Baraliakos X. Is undifferentiated spondyloarthritis a discrete entity? A debate. Autoimmun Rev 2018;17(1):29-32. doi: 10.1016/j. autrev.2017.11.006 [published Online First: 2017/11/08].

[3] Sheth T, Pitchumoni CS, Das KM. Management of Musculoskeletal Manifestations in Inflammatory Bowel Disease. Gastroenterol Res Pract 2015;2015:387891. doi: 10.1155/2015/387891 [published Online First: 2015/07/15].

[4] Fragoulis GE, Liava C, Daoussis D, et al. Inflammatory bowel diseases and spondyloarthropathies: From pathogenesis to treatment. World J Gastroenterol 2019;25(18):2162-76. doi: 10.3748/wjg.v25.i18.2162 [published Online First: 2019/05/31].
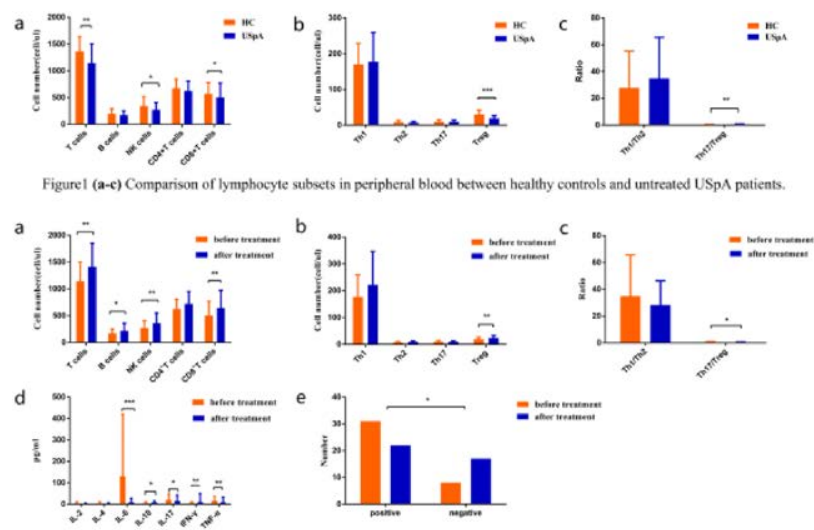

Figure2 (a-c) Variation of peripheral lymphocyte subsets cytokines after regulation of intestinal flora. (d) Variation of after regulation
of intectinal flora (e) Change of positive rate of methane hydrogen breath fest after treatment. $* P<0.05, * * P<0.01, \cdots * P<0.001$.

Acknowledgements: This project was supported by National Science Foundation of China (82001740), Open Fund from the Key Laboratory of Cellular Physiology (Shanxi Medical University) (KLCP2019) and Innovation Plan for Postgraduate Education in Shanxi Province (2020BY078).

Disclosure of Interests: None declared DOI: 10.1136/annrheumdis-2021-eular.3004 